\title{
Pengembangan Desain Produk Berbahan Bambu dengan Menggunakan Strategi Desain di Nagari Kumanis Sijunjung (Studi Kasus ; UKM Kerajinan Bambu di Nagari Kumanis, Kabupaten Sijunjung)
}

\author{
Kendall Malik $^{1)}$, Ferry Fernando ${ }^{2)}$, Silvi Amalia ${ }^{3)}$ \\ ${ }^{1223)}$ Program Studi Desain Komunikasi Visual, Institut Seni Indonesia Padangpanjang \\ Jalan Bahder Johan No.35 Padangpanjang 27128. Padangpanjang Sumatera Barat \\ Email :kendall.malik@gmail.com ${ }^{1)}$, azaliahanessa@gmail.com ${ }^{2}$, Shilviamalia29@gmail.com $^{3)}$
}

\begin{abstract}
The research focused is on bamboo crafts in Nagari Kumanis, Sijunjung Regency, about the use of bamboo material as a potential product using a design strategy. Bamboo production areas in West Sumatra are mostly produced in Sumpur Kudus district in Nagari Tanjung Bonai Aur and Kumanis, Sijunjung Regency. Nagari has a group called Talago Bamboo Crafts. One of the bamboo handicraft centers that has long been developing in West Sumatra is the Tanjung Bonai Aur and Kumanis bamboo crafts. It is known that bamboo crafts in Kumanis nagari are quite unique in terms of technical aspects, but in the aspect of design strategies and market strategies of bamboo products have not been explored properly. So that the economic and production cycle moves in place. Bamboo plantations in West Sumatra belong to communities that are managed independently by the population. Bamboo in the Kumanis nagari community is important by the economic wheel and their economic bamboo efforts as a side job. In fact, Minang residents already have a bamboo garden that is indirectly as a bamboo farmer. This is an opportunity for writers in this design project to provide ideas and design ideas to communities and small industries (homeindustry). In fact, bamboo material has not been specially processed for product design, especially for bamboo product design and Design Strategies. the problem of this research is how to improve, process and utilize bamboo material as one of the development of interior complementary designs and in accordance with market needs and tastes.
\end{abstract}

Keywords : Bamboo, Product Design, Design Strategy, Kumanis

\begin{abstract}
Abstrak
Penelitian yang difokuskan adalah mengenai kerajinan bambu di Nagari Kumanis Kabupaten Sijunjung tentang pemanfaatan material bambu sebagai produk potensial dengan menggunakan strategi desain. Daerah produksi bambu di Sumatera Barat sebagian besar diproduksi di kabupaten Sumpur Kudus di Nagari Tanjung Bonai Aur dan Kumanis, Kabupaten Sijunjung. Nagari memiliki kelompok yang disebut Kerajinan Talago Bambu. Salah satu pusat kerajinan bambu yang telah lama berkembang di Sumatera Barat adalah kerajinan bambu Tanjung Bonai Aur dan Kumanis. Diketahui bahwa kerajinan bambu di nagari Kumanis cukup unik dalam hal aspek teknis, namun dalam aspek strategi desain dan strategi pasar produk bambu belum dieksplorasi dengan baik. Sehingga siklus ekonomi dan produksi bergerak di tempat. Perkebunan bambu di Sumatera Barat adalah milik masyarakat yang dikelola secara mandiri oleh penduduk. Bambu dalam masyarakat nagari Kumanis adalah penting oleh roda ekonomi dan upaya bambu ekonomi mereka sebagai pekerjaan sampingan. Bahkan, warga Minang telah memiliki kebun bambu yang secara tidak langsung sebagai petani bambu. Ini adalah kesempatan bagi penulis dalam proyek desain ini untuk memberikan ide dan ide desain kepada komunitas dan industri kecil (homeindustry). Padahal, bahan bambu belum diolah secara khusus untuk desain produk, terutama untuk desain produk bambu dan Strategi Desain. permasalahan dari penelitian ini adalah bagaimana meningkatkan, mengolah dan memanfaat material bambu sebagai salah satu perkembangan desain pelengkap interior dan sesuai dengan kebutuhan dan selera pasar.
\end{abstract}

Kata kunci: Bambu, Desain Produk, Strategi Desain, Kumanis 


\section{Pendahuluan}

\section{A. Latar Belakang}

Sumatera Barat atau Minangkabau yang penuh dengan budaya dan tradisi, mulai dari sistem pernikahan, musik tradisional, tenun tradisional, tarian tradisional rakyat sampai berbagai bentuk kerajinan tangan yang dimiliki oleh daerah Sumatera Barat. Masyarakat Minang, mempunyai latar belakang kebudayaan yang khas. Kerajinan tangan masyarakat Minangkabau bermacam jenisnya, bentuk kerajinannya antara lain kerajinan kulit, kerajinan keramik, kerajinan rotan, kerajinan logam, kerajinan tekstil. Di antara sekian banyak kerajinan tangan yang dihasilkan oleh masyarakat Minang cuma bambu yang belum diproduksi dan dikembangkan secara desain oleh masyarakat Minangkabau.

Daerah penghasilan bambu di Sumatera Barat sebagian besar dihasilkan di Kecamatan Sumpur Kudus di Nagari Tanjung Bonai Aur dan Kumanis Kabupaten Sijunjung. Dimana nagari ini telah memiliki kelompok yang bernama Kerajinan Bambu Talago. Salah satu sentra kerajinan bambu yang telah lama berkembang di Sumatera Barat adalah kerajinan bambu Tanjung Bonai Aur dan Kumanis. Namun diketahui meskipun kerajinan bambu Nagari Tanjung Bonai dan Aur dan Kumanis tergolong unik dari segi teknisnya, namun dari segi cirikhas dan identitas produk bambunya belum terekplorasi dengan baik termasuk produk bambunya belum memenuhi kebutuhan dan selera pasar dengan baik. Sehingga perputaran ekonomi dan produksi bergerak jalan ditempat. Padahal bambu berperan bagi hajat hidup masyarakat Minangkabau. Perkebunan bambu di Sumatera Barat merupakan kebun milik rakyat yang dikelola oleh penduduk secara mandiri. Bambu yang terdapat di masyarakat Minang sangat berperan penting bagi roda perekonomian masyarakat, boleh dikatakan sebagai usaha sampingan untuk membantu perekonomian mereka. Kenyataan tersebut dapat dilihat di mana sebagian besar penduduk Minang memiliki kebun bambu yang secara tidak langsung juga menjadi petani bambu.

Alam Sumatera Barat yang kaya dengan bambu merupakan lingkungan yang strategis untuk pertumbuhan bambu. Rumpun - rumpun bambu yang demikian lebat ternyata memiliki persoalan pada pemanfaatan dan pengembangan secara desain produk bambu. Melalui gagasan penulis dalam memanfaatkan material bambu sebagai bahan baku alternative kerajinan. Maka, untuk projek desain ini akan memfokuskan studi desain produk yang menggunakan bahan dasar bambu yaitu pemanfatan bambu pada pengembangan produk khususnya pengembangan pelengkap interior. Dalam bahasa Minang, bambu disebut dengan aua, buluah, atau bilah yang artinya bambu. Bambu biasanya digunakan oleh masyarakat kampung Minang adalah untuk pagar rumah, kandang ternak, penyanggah coran semen rumah, keramba ikan, tempat duduk di sawah dan lain-lain. Di lihat dari fenomena ini bahwa bambu belum dimanfaatkan secara optimal oleh masyarakat Minang. Hal ini menjadi peluang bagi penulis dalam proyek desain ini untuk memberikan ide dan gagasan desain pada masyarakat dan industri kecil (homeindustry). Sejauh ini bahan bambu masih belum diolah khusus untuk desain produk khususnya desain produk bambu. Di mana sumber daya alam (SDA) dan sumber daya manusia (SDM) di Minangkabau banyak terdapat menggunakan bahan bambu.

\section{B. Permasalahan}

Penelitian yang difokuskan adalah mengenai kerajinan bambu di Nagari Kumanis Kabupaten Sijunjung tentang pemanfaatan material bambu sebagai produk potensial dengan menggunakan strategi desain. Berdasarkan hasil survey bahwa perlu dilakukan peningkatan dalam mengolah dan memanfaatkan bambu untuk pelengkapan produk barang pakai dimana material bambu ini dapat menjadi potensi di pasar dan mengejar selera pasar. Hal ini produk bambu yang dihasilkan pada saat sekarang ini mengelami penurunan minat pembeli dan pengembangan desain yang berbahan di nagari Kumanis Sijunjung dikarenakan bahan bambu belum terolah secara sempurna sampai kepada produk, sehingga produk belum memenuhi kebutuhan pasar dan selera pasar. Berdasarkan itu permasalahan dari penelitian ini adalah bagaimana meningkatkan mengolah dan memanfaat material bambu sebagai salah satu perkembangan desain pelengkap interior dan sesuai dengan kebutuhan dan selera pasar. Bagaimana mengembangkan produk yang berbahan bambu ini dapat menjadi produk potensial yang dimiliki oleh nagari Kumanis di Kabupaten Sijunjung.

\section{Tujuan}

1. Mendesain produk barang pakai yang menggunakan material bambu dengan pendekatan strategi desain produk di Nagari Kumanis Sijunjung.

2. Memberikan gagasan dan ide bagi pengembangan industeri kecil (home industry) khususnya yang bergerak di bidang bambu.

3. Mengembangkan material bambu sebagai sumber daya alam (SDA) yang terdapat di Nagari Kumanis Sijunjung Sumatera Barat untuk pengembangan desain produk barang pakai.

4. Mengembangkan desain produk bambu, untuk mengangkat, melestarikan dan memperkaya tradisi budaya Minangkabau untuk diterapkan bagi pengembangan industri kecil (home industri) di Sumatera Barat.

5. Desain produk bambu ini dapat menjadi produk bambu sebagai cirikhas masyarakat nagari Kumanis Minangkabau dan menjadi tradisi di lingkungan masyarakat Minang.

\section{Pembahasan}

\section{A. Mengenal Bambu}

Alam kita banyak menemukan berbagai macam tumbuhan mulai dari sayur - sayuran, pohon, bunga - 
bunga, dan lain - lain. Bambu biasanya digunakan untuk bahan-bahan bagian bangunan karena bambu jauh lebih murah dan mudah ditemukan. Bambu terdapat hampir di seluruh Indonesia. Pada umumnya bambu digunakan sebagai bahan peganti kayu bagi penduduk desa yang mempunyai kebiasaan menanam di halaman rumah atau di bagian belakang rumah.

\section{B. Jenis - Jenis Bambu}

Dalam buku Bambu, oleh Anang Sumarja (Sumarja : 2007) menjelaskan bahwa pada bambu terdapat 17 jenis bambu di Indonesia :

1. Bambu Ampel (Bambusa Vulgaris var.viridis)

Berbuluh hijau mengkilat dan biasa ditanam sebagai batas kebun. Bambu ampel hanya ditemukan ditaman orang, sedangkan bambu tutul masih dijumpai liar di Sumbawa Sumba, dan Maluku.

2. Bambu Ater (Gigantochloa atter)

Orang Jawa disebut 'pring legi' karena rebungnya manis. Bambu ini baik untuk membuat alat musik maupun anyam - anyaman, tusuk gigi serta tusuk satai. Kerabat dekatnya sedangkan bambu ater terdapat di segala tempat dan tersebar luas di Indonesia.

3. Bambu Bali

Disebut bambu gading oleh orang Bali dan biasa digunakan dalam upacara ngaben. Juga dipakai untuk tanaman hias karena buluhnya yang indah kekuningan.

4. Bambu Betung (Dendrocalamus asper)

Rebungnya biasa untuk sayur. Buluhnya berdiameter hingga 12 sentimeter dengan dinding relatif tebal sehingga biasa digunakan untuk tiang rumah, jembatan, dan bahan bangunan lainnya.

5. Bambu Buta (Schizostachyum Caudatum)

Merupakan satu - satunya bambu yang pejal dan tumbuh hanya di Sumatera Selatan. Di Bengkulu bambu ini dikenal dengan nama bambu bungkok. Selain berpuluh pejal, diameternyapun hanya berkisar 3 sentimeter dan tingginya 6 meter.

6. Bambu Cangkoreh (Dinochloa Scandens)

Bambu ini tumbuh di daratan rendah. Menjalar seperti rotan, banyak terdapat di hutan - hutan primer Indonesia. Warna buluh hijau tua, serta bermiang kasar. Buku - bukunya membengkak dan berwarna coklat. Buluhnya sangat ulet dan kuat, dipakai untuk anyaman atau tali pada anyaman lain.

7. Bambu Cina

Merupakan bambu pendatang yang semula diperkenalkan sebagai tanaman hias dan pagar hidup, disebut juga bambu pagar. Mempunyai kerabat antara lain bambu swis yang biasa ditanam di pot atau sebagai bambu hias yang dipangkas.

8. Bambu Duri

Tinggi buluh mencapai 25 meter dengan garis tengah 10 centimeter. Bambu duri digunakan sebagai bahan anyaman dan bahan bangunan. Juga sangat baik untuk bahan kertas.

9. Bambu Eul - eul (Nastus elegantissimus)
Biasa tumbuh liar, dan hanya terdapat di hutan hutan di daerah Pangalengan, Jawa Barat. Bambu ini mempunyai buluh yang tipis, ruasnya mencapai 1 meter, tingginya hingga 20 meter.

10. Bambu Gendang

Merupakan satu - satunya bambu yang mempunyai ruas berlekuk - lekuk seperti gendang. Bambu ini banyak digemari sebagai bambu hias yang ditanam di pot.

11. Bambu Gombong (Gigantochloa verticillata)

Buluhnya berwarna hijau kekuning - kuningan dengan garis - garis kuning yang sejajar dengan buluhnya. Tinggi buluh dapat mencapai 20 meter, garis tengahnya 10 centimeter. Potensi ekonominya besar.

12. Bambu Jepang,

Merupakan satu - satunya jenis bambu yang berasal dari Thailand dan di Indonesia dikenal hanya sebagai tanaman hias, walau di negara asalnya merupakan bahan baku kertas yang paling baik.

13. Bambu Lengka (Gigantochloa nigrociliata)

Bambu ini tidak banyak diusahakan oleh karena buluhnya tidak tahan lama bila digunakan untuk bahan - bahan bangunan. Rebungnya dapat dimakan.

14. Bambu Regen

Tumbuh di Sumatera Utara dan digunakan untuk menjolok buah kelapa sawit. Pada mulanya bambu yang mempunyai miang hitam, panjang dan lebat ini hanya diambil buluhnya untuk membuat 'parhalaan', Penduduk sekitar hutan memanfaatkannya untuk segala keperluan sehari - hari dari membuat rumah sampai balai - balai.

15. Bambu Suling

Berbuluh tipis dengan ruas panjang - panjang sangat cocok untuk membuat suling. Di Jawa digunakan jenis yang secara lokal disebut bambu tamiang. Selain untuk membuat suling, jenis bambu ini banyak digunakan untuk membuat tangkai pancing. Dalam perang kemerdekaan dulu bambu tamianglah yang digunakan untuk membuat bambu runcing.

16. Bambu Uncu

Jenis bambu ini berasal dari Jepang. Buluhnya tegak, tingginya sampai 6 meter, dengan garis tengah 2-3 centimeter. Panjang ruasnya 25 centimeter kadang kadang sampai 40 centimeter. Ada dua macam bambu yang mempunyai buluh beruas pendek ini, yaitu yang berwarna hijau dan yang berwarna kuning.

17. Bambu Loleba

Merupakan bambu yang hanya tumbuh di Indonesia Timur (Maluku, Irian Jaya, dan bagian timur Sulawesi). Inilah satu - satunya bambu yang masih dapat tumbuh di tempat berawa. Buluhnya kecil dengan diameter hanya 2 centimeter dan terdiri atas hanya tiga ruas yang panjangnya mencapai sekitar 1 meter, sehingga tumbuhan ini hanya mencapai kurang lebih 4-5 meter. Di daerah asalnya bambu ini sering digunakan untuk membuat anak panah. 
Bambu menjadi bahan yang berkaitan dengan pola ritual tradisional di daerah Jawa Barat. Bambu sepertinya tidak dapat dipisahkan dari kehidupan manusia Sunda. Hal ini dapat dilihat dalam kehidupan sehari - hari.

\section{Cara Pengawetan Bambu}

Dalam buku "Ilmu Konstruksi Bangunan Bambu"(Heinz Frick,2004) menjelaskan bahwa pada pengawetan bambu terdapat 2 cara yaitu cara tradisional dan cara kimiawi.

\section{Cara Tradisional}

Cara perawatan secara tradisional adalah dengan merendam batang bambu sebalum digunakan selama satu bulan di dalam air tawar, air payau, atau air laut yang tenang atau mengalir sehingga kandungan kanji akan dicuci atau hilang. Kemudian batang bambu yang baru dipotong sebaiknya disandarkan dalam keadaan berdiri pada bambu yang belum di potong di tempatkan yang teduh. Cara perawatan yang menggunakan api. Api dan asapnya akan membasmi hama yang berada di dalam batang bambu dan memperkeras permukaan bambu.

2. Cara Kimiawi

Pengawetan bambu secara kimiawi diawetkan dengan lima cara, yaitu pengawetan dengan perendaman batang atau bilah bambu, cara pengaliran dan cara penekanan, penyimpanan dalam drum besi, serta pengecatan dengan zat penolak serangga. Di bawah ini akan dijelaskan satu persatu:

a. Pengawetan dengan perendaman

Batang atau bilah bambu merupakan cara yang paling sederhana. Batang (atau bilah) bambu direndam dalam bahan pengawet dengan atau tanpa tangkainya. Penganwetan dengan perendaman hanya dapat dilakukan dengan bambu yang baru dipotong (bukan kering), cara ini memerlukan 2-5 hari.

b. Pengawetan dengan cara pengaliran

Merupakan cara yang dianggap paling efisien. Batang bambu yang baru dipotong (termasuk tangkai dan daunnya) disambung dengan siang pada ujung kakinya pada drum besi yang mengandung bahan pengawet. Bahan pengawet tersebut akan mengalir dalam batang bambu sampai pada puncaknya. Sisa bahan pengawet yang mengalir keluar pada puncak dapat digunakan kembali selama konsentrasinya terjamin.

c. Pengawetan dengan cara penekanan

Merupakan cara yang lebih cepat sehingga tidak perlu di tunggu 2-5 hari tersebut di atas. Pada cara ini drum besi yang mengandung bahan pengawet harus rapat udara sehingga dapat dilengakapi dengan pompa udara yang akan menekan bahan pengawet ke dalam batang bambu.

d. Mengecat dengan zat penolak serangga

Daun dari pohon imbau dihancurkan dan digilas sehingga menghasilkan sari daun. Karena sari tersebut mengandung insektisida alam, maka sari ini dapat dicatkan pada batang dan konstruksi bambu yang sudah dalam keadaan kering sehingga menolak serangga. Bahan bangunan bambu yang sudah dalam keadaan kering selalu harus dilindungi dari air hujan maupun embun.

D. Pemanfaaatan Bambu sebagai Media Utama bagi Masyarakat Kumanis Sijunjung

Nagari Kumanis merupakan salah satu negeri yang terpilih negeri yang berprestasi ditingkat Provinsi Sumatera Barat pada tahun 2018. Negeri Kumanis ini mewakili dari Kabupaten Sijunjung sebagai nagari berprestasi. Hal ini nagari ini memiliki potensi-potensi yang dimilikinya. Nagari Kumanis Sijunjung memiliki potensi SDA (Sumber Daya Alam) yang beragam diantaranya getah/karet, gula aren, gula semut, sawit dan bambu. Namun semua SDA ini dikelola oleh masyarakat. Menurut salah satu pemuka masyarakat di Kumanis Sijunjung bernama bapak Yul Firdaus menyatakan bahwa masyarakat Kumanis bekerja sebagai petani kebun. Rata-rata masyarakat di Kumanis memiliki kebun karet, sawit, dan usaha gula aren yang dikelola secara tradisional kecuali bambu yang tidak dikelola dengan baik dimana bambu hanya tumbuh secara liar didalam kebun dan hutan. (Wawancara dengan Bapak Yul Firdaus pada tanggal 07 September 2019 pada pukul 10.00 s.d 11.00 WIB). (Lihat Gambar 1).

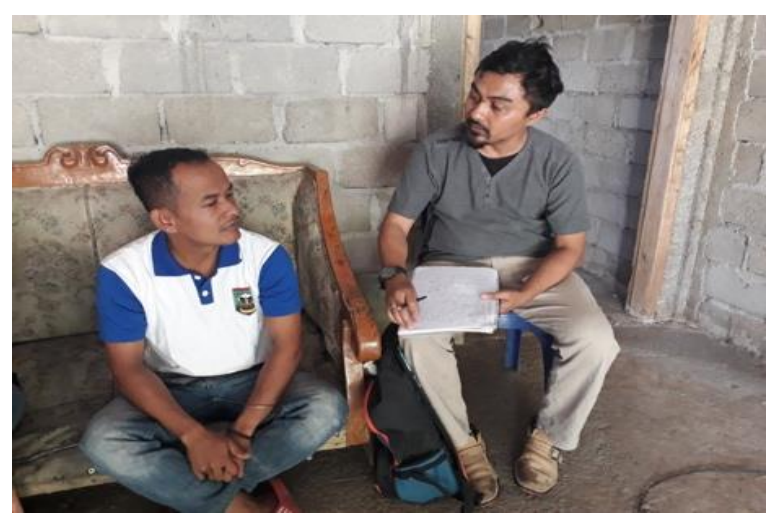

Gambar 1. Wawancara dengan Bapak Yul Firdaus salah Satu Pemuka Masyarakat dan Ketua UKM Kerajinan Kumanis Sijunjung (Dokumentasi : Muhammad Iqbal, 2019)

Nagari Kumanis Sijunjung memiliki tumbuhan bambu yang tumbuh liar di kebun dan hutan. Hal ini masyarakat memanfaatkan bambu - bambu tersebut pada kebutuhan-kebutuhan penunjang seperti kandang sapi/ayam untuk ternak, pagar untuk kebun, pagar untuk rumah, pagar untuk hiasan taman desa yang berada di kantor Wali Nagari Kumanis, dan juga sebagai pembungkus untuk memasak lemang (makanan tradisional), dan bahan utama untuk kerajinan, dan lain sebagainya. (Lihat Gambar 2). 


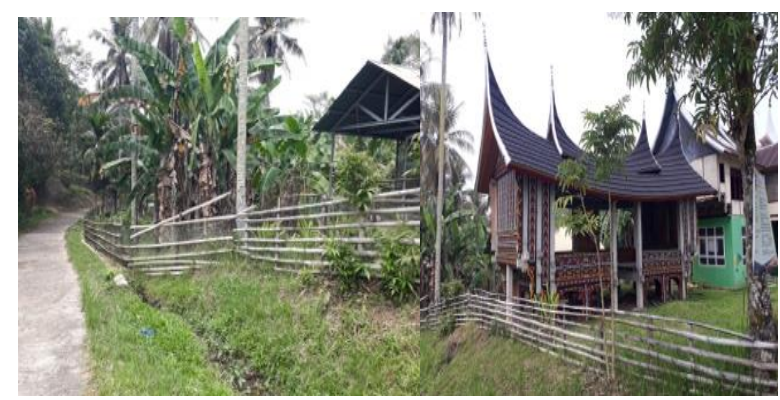

Gambar 2. Pemanfaatan Bambu oleh Masyarakat di Nagari Kumanis Sijunjung, Sumatera Barat

(Dokumentasi : Kendall Malik, 2019)

Bahan bambu ini sedang dikembangkan oleh anak nagari Kumanis ini sebagai media utama untuk produk kerajinan yang bercirikhas Kumanis Sijunjung. Sehingga produk lokal anak Nagari Kumanis ini memiliki identitas, nilai jual, nilai ekonomi dan nilai budaya yang sesuai dengan lingkungan, social, budaya dan tradisional Nagari Kumanis Sijunjung.

\section{E. Latar Belakang Produk Bambu sebagai Media Utama Kerajinan Nagari Kumanis Sijunjung}

Produk bambu yang dikembangkan oleh anak Nagari Kumanis Sijunjung berawal dari adanya pelatihan pengabdian kepada masyarakat tentang pengolahan dan pengembangan produk bambu yang sebagai ketua pengabdian kepada masyarakat (PKM) yaitu Bapak Ahmad Baharudin, S.Sn., M.Sn dimana yang berlangsung pada bulan Juli 2017, kemudian pelatihan tersebut berlanjut pada tahun berikutnya pada bulan Agustus 2018 dengan tema dan luaran yang sama. Hasil dari pelatihan PKM tersebut menjadi potensi bagi masyarakat Kumanis Sijunjung yang dapat mengembangkan kerajinan bambu yang menghasilkan produk - produk penunjang interior yang berbahan bambu. Produk-produk yang dibuat oleh pengrajin meliputi lampu duduk, lampu gantung, lampu dinding, gelas bambu, tempat gula semut. Melihat potensi ini yang menghasilkan income (pendapatan) bagi masyarakat nagari Kumanis Sijunjung maka atas dukung bapak Wali Nagari dan Bupati Sijunjung meresmikan untuk membentuk sebuah Usaha Kecil Menengah (UKM) Kerajinan Bambu untuk nagari Kumanis Sijunjung pada tanggal 02 Februari 2019 s.d sekarang dimana dikelola oleh anak nagari Kumanis Sijunjung. (Wawancara dengan Bapak Yul Firdaus selaku Ketua UKM di nagari Kumanis Sijunjung, pada tanggal 07 September 2019, jam 10.00 s.d 11.00).

UKM kerajinan bambu nagari Kumanis Sijunjung ini diawal menghasilkan produk-produk yang masih focus pada cup lampu seperti lampu duduk, lampu gantung, lampu dinding dan sekrang ada beberapa produk lainnya yang akan dikembangkan seperti tempat gula, kopi dan teh. Hal ini UKM kerajinan bambu Nagari Kumanis Sijunjung akan berkembang dengan pesat dengan menawarkan identitas-identitas local yang yang berasal dari lingkungan social dan budaya nagari Kumala Sijunjung. (Lihat Gambar 3).

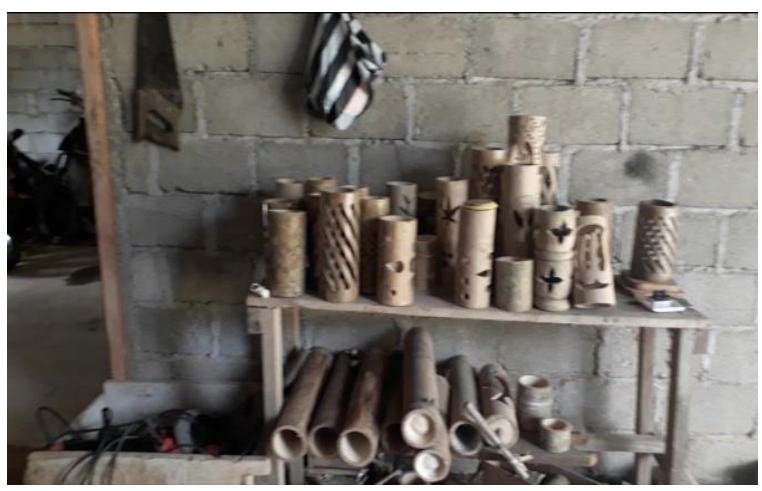

Gambar 3. Hasil Produk Karya Lokal dari UKM

Kerajinan Bambu di Nagari Kumanis Sijunjung, Sumatera Barat (Dokumentasi : Kendall Malik, 2019)

Pemanfaatan bambu sebagai bahan utama bagi UKM kerajinan bambu nagari Kumanis Sijunjung ini dikarenakan tumbuhan bambu yang tumbuh secara liar dikebun-kebun yang dimiliki oleh masyarakat. Hal ini menjadi peluang bagi pengrajinan nagari Kumanis Sijunjung. Salah satu pengrajin dan ketua UKM kerajinan Bambu nagari Kumanis Sijunjung yaitu bapak Yul Firdaus dan Joko Saputra menyatakan bambu di sini sangat mudah didapat karena bambu tersebut hidup di hutan dan kebun-kebun masyarakat dan bambu itu didapat secara gratis (tidak bayar). Hal ini menjadi peluang bagi pengrajin dan pengembangan produk bambu yang berasal dari nagari Kumanis Sijunjung. (Wawancara dengan Bapak Yul Firdaus dan Joko Saputra pada tanggal 07 September 2019 pukul 10.00 s.d 11.00 WIB).

\section{F. Konsep (Strategi Desain)}

1. Tahap Pembuatan Produk Bambu

Pembuatan produk menggunakan jenis bambu tali yang bentuknya lurus, berumur tua dan sudah kering, dengan ukuran panjangnya 4 s.d 5 meter. Bambu dipilih yang sudah kering atau sudah berwarna kuning. Pembuatan produk menggunakan semi mesin yang berarti setengah dikerjakan secara manual dan setengah lagi dikerjakan menggunakan mesin. Bambu dipotong sesuai dengan kebutuhan produk dan ukuran produk yang diinginkan. Kemudian teknik pengeleman dengan menggunakan lem kayu dan diamplas secara merata. Dalam teknik finishing menggunakan pernis sebagai pengkilat supaya bambu terlindung dari rayap dan bambu terlihat awet dan kuat.

2. Tahap Penerapan Produk

a. Aspek Pengguna

Dalam aspek ini ditentukan target dan kriteria pengguna untuk menentukan kriteria dan nilai pada produk bambu ini nantinya. (Lihat tabel 1). 
Tabel 1. Kriteria dan Nilai pada Pengguna

\begin{tabular}{|c|c|c|}
\hline No & Kriteria & Nilai \\
\hline 1 & SARA & Bebas \\
\hline 2 & Kelompok Masyarakat & Bebas \\
\hline 3 & Jenis Kelamin & Bebas \\
\hline 4 & Umur & 10 tahun keatas \\
\hline 5 & Profesi & Bebas \\
\hline 6 & Kebiasaan/perilaku/habit & Bebas \\
\hline 7 & Kondisi ekonomi social & Bebas \\
& budaya & Bebas \\
\hline 8 & Kondisi Fisik & Bebas \\
\hline 9 & Religi dan Kepercayaan & \\
\hline
\end{tabular}

b. Aspek Spesifikasi dan Kriteria Bambu

Perancangan berbahan bambu tentunya harus memiliki spesifikasi dan kriteria bambu yang akan digunakan untuk pengembangan produk. Spesifikasi dan kriteria bambu meliputi :

Tabel 2. Spesifikasi dan Kriteria Bambu

\begin{tabular}{|c|c|c|c|c|}
\hline No & Bambu & Cirikhas & Fungsi & Ket. \\
\hline 1 & Bambu Betung & $\begin{array}{l}\text { a.Berdiameter } \\
12 \text { sentimeter. } \\
\text { b.Dinding } \\
\text { relative tebal. } \\
\text { c.Rebungnya } \\
\text { bisa dijadikan } \\
\text { sayur. }\end{array}$ & $\begin{array}{l}\text { a.Tiang } \\
\text { Rumah. } \\
\text { b.Jembatan. } \\
\text { c.Bahan } \\
\text { Bangunan }\end{array}$ & $\begin{array}{l}\text { a.Kuat } \\
\text { b.Dijadikan } \\
\text { bahan untuk } \\
\text { Kerajinan. }\end{array}$ \\
\hline 2 & $\begin{array}{l}\text { Bambu Gombong } \\
\text { (Batuang/Buluah) }\end{array}$ & $\begin{array}{l}\text { a.Berwarna } \\
\text { hijau } \\
\text { kekuning- } \\
\text { kuningan, } \\
\text { Garis-garis } \\
\text { kuning sejajar } \\
\text { dengan } \\
\text { buluhnya. } \\
\text { b.Tinggi } \\
\text { buluh } \\
\text { mencapai } 20 \\
\text { meter. } \\
\text { c.Garis tengah } \\
\text { 10 sentimeter. }\end{array}$ & $\begin{array}{l}\text { a.Bahan } \\
\text { b.Bangunan. } \\
\text { c.Bahan untuk } \\
\text { furniture/mebel } \\
\text { d.Perkakas } \\
\text { rumah tangga. }\end{array}$ & $\begin{array}{l}\text { a.Bagus untuk } \\
\text { perekonomian. } \\
\text { b.Potensi } \\
\text { ekonomi besar. } \\
\text { c.Dijadikan } \\
\text { bahan untuk } \\
\text { kerajinan. }\end{array}$ \\
\hline
\end{tabular}

c. Aspek Desain Produk Bambu

Pada aspek disain produk tentunya memperhitungkan beberapa ruanglingkup, meliputi :

a. Segi Fungsi, merupakan produk yang dapat sebagai penunjang interior atau sebagai pelengkap bagi suatu ruangan.

b. Segi Ergonomi, merupakan produk yang harus memperhitungkan keselamatan, nyaman dan aman, disamping itu juga mengikuti standar antropometri Indonesia.

c. Segi Ekonomi, mempertimbangkan prinsipprinsip ekonomi yang mana menyangkut kearah efisiensi, efektifitas dan kualitas produk.

d. Segi Psikologis, mempertimbangkan emosi, kebiasaan dan kelakuan pengguna supaya produk dapat memberi image aman, nyaman dan menciptakan suasana senang.

e. Segi Teknis, merupakan produk yang menggunakan proses produksi yang kuat, akurat dan pemanfaatan teknologi yang tepat.

f. Segi Sosial, perancangan produk ini mempertimbangkan dan mempengaruhi kehidupan social dikalangan masyarakat dan beradaptasi sesuai kondisi sosial dan budaya. Segi social ini juga mempertimbangkan identitas budaya setempat.

g. Segi Lingkungan, merupakan lingkungan yang sangat mendukung untuk pertumbuhan bamboo sebagai bahan baku dalam pengembangan produk bamboo.

h. Segi Visual, perancangan mengarahkan bentuk mengikuti identitas (form following identity) untuk meningkatkan kualitas pada visual produk.

d. Aspek Data Antropometri

Untuk pengumpulan data antropometri di lingkungan masyarakat maka dilakukan studi mulai dari ukuran tinggi badan, ukuran jangkauan handle, tinggi mata, tinggi pundak, tinggi siku, tinggi kaki, berat badan dan panjang telapak kaki pada saat menggunakan produk bambu. (Lihat Tabel 3).

Tabel 3. Ukuran Tubuh Manusia Sesuai dengan Ukuran Antropometri

\begin{tabular}{|c|c|c|c|c|}
\hline \multicolumn{5}{|c|}{ Antropomet } \\
\hline & & Pendek & Rata & Tinggi \\
\hline \multicolumn{5}{|c|}{ Berdiri (cm) } \\
\hline 1 & Tinggi & 146.0 & 164.0 & 170.0 \\
\hline 2 & $\begin{array}{c}\text { Jangkauan } \\
\text { Handle }\end{array}$ & 30.0 & 30.0 & 35.0 \\
\hline 3 & Tinggi Mata & 140.0 & 145.0 & 164.0 \\
\hline 4 & Tinggi Pundak & 116.0 & 130.0 & 145.0 \\
\hline 5 & Tinggi Siku & 92.0 & 100.0 & 110.0 \\
\hline 6 & $\begin{array}{l}\text { Tinggi Kaki } \\
\text { (step) }\end{array}$ & 66.0 & 73.8 & 82.5 \\
\hline 7 & Berat Badan & 40.0 & 62.0 & 70.0 \\
\hline 8 & $\begin{array}{c}\text { Panjang Telapak } \\
\text { Kaki }\end{array}$ & 24.0 & 24.0 & 25.0 \\
\hline
\end{tabular}

e. Aspek Produksi

Produk yang akan dirancang menggunakan semi teknologi dimana memiliki beberapa mesin potong, mesin gergaji triplek, mesin ketam, dan mesin amplas listrik. Sedangkan yang manual menggunakan gergaji dan parang.

Proses pembuatan dengan berbahan bambu harus dipotong dulu dengan menggunakan parang atau dengan gergaji. Kemudian bambu dipotong sesuai dengan kebutuhan dan disesuaikan dengan Ukuran yang sudah ada pada desain. Dalam potonganpotongan kecil bambu menggunakan mesin amplas supaya tidak tajam pada permukaan bambu dimana untuk menghindari terjadi luka pada bagian tangan. Bambu yang sudah diamplas dan digarinda secara halus maka bambu tersebut dirakit dengan menggunakan lem kayu dan lem harus kering merata pada permukaan bambu. Pada bagian finishing menggunakan pernis sebagai pelindung permukaan bambu dan pengkilat untuk menambah keindahan pada produk bambu.

\section{G. Tahapan Manajemen Desain}

Perancangan sebuah produk desain tentunya memiliki sebuah manajemen yang tepat dan memiliki metode yang tepat. Hal ini dalam manajemen desain 
penulis memfokuskan dua perhatian khusus untuk penelitian desain produk bambu ini, meliputi :

1. Menyelidiki permasalahan manajemen dan pertanggungjawaban peraturan dari dalam (intren influence) yang merupakan salah satu yang mempengaruhi suatu produk.

2. Menggali informasi tentang metode manajemen dan pendekatannya.

Salah satu mengelola sebuah perancangan adalah menjaga kualitas produk yang dipengaruhi oleh kualitas produksi, kualitas desain dan kualitas budaya dan lingkungannya.

\section{H. Tahapan Pengembangan Desain}

Menurut Karl T.Ulrich (1995:03) menyatakan bahwa pengembangan desain merupakan kegiatan yang disetting dari awal dengan persepsi peluang pasar dan diakhiri dengan produksi, penjualan, dan mengantarkan produk. Pengembangan desain ini memiliki lima karakter yang sukses dalam pengembangan desain, meliputi :

1. Kualitas Produk (Product Quality) merupakan secara mendasar mereflekkan sebaran dipasaran dan harga yang dengan senang hati yang dibayarkan oleh konsumen.

2. Harga Produk (Product Cost) merupakan biaya termasuk proses produksi selama memproduksi persatuan unit produk termasuk peralatan utama dan penunjang. Di samping itu berapa profit, penjualan dan harga jual.

3. Waktu Pengembangan (Development Time) merupakan seberapa lama waktu yang dihabiskan dan dibutuhkan dalam pengembangan produk dan termasuk pengembangan teknologinya. Hal ini juga menyangkut seberapa besar modal bisa kembali kepada tim pengrajin bambu.

4. Perkembangan Biaya (Development Price) merupakan biaya yang biasanya meningkat dimana untuk mencapai keberhasilan profit yang tinggi.

5. Kemampuan dalam Mengembangkan (Development Capability) merupakan kemampuan memperhitungkan dan memikirkan produk yang akan datang melalui hasil pengalaman dari produk sebelumnya. Kemudian kemampuan dalam mengembangkan produk ini sebagai asset untuk mengembangkan produk yang lebih efisien dan ekonomis di masa akan datang.

\section{Tahapan Mengkonsep Desain}

Pengaplikasian konsep pada produk bambu, penulis menerapkan penggabungan konsep budaya sebagai identitas Nagari Kumanis, Sijunjung. Penulis akan memaparkan konsep ini ke dalam desain, sebagai berikut.

1. Batasan Desain

Batasan Desain Produk bamboo Nagari Kumanis sebagai berikut :

a. Portable - Produk dapat diletakkan dimana saja.

b. Simple - Mudah digunakan dan tidak rumit. c. Cultural - Produk memiliki visual yang berkonten muatan budaya lokal.

d. Natural - Bahan menggunakan bahan dari alam yaitu bambu.

e. Identity - Produk mencerminkan identitas budaya Nagari Kumanis, Sijunjung.

f. Modren - Produk berinovasi dan memiliki daya tarik.

2. Karakter Desain

Karakter Desain Bambu Nagari Kumanis, sebagai berikut :

a. Tidak berbahaya - Produk berasal dari bahan alami sehingga bisa digunakan dalam jangka waktu yang lama.

b. Mudah dioperasikan - Produk sangat mudah dioperasikan secara manual.

c. Fungsional - Produk sangat berfungsi dengan baik dan dapat difungsikan sesuai kebutuhan sehari-hari.

d. Sosial - Masyarakat nagari Kumanis Sijunjung mempunyai rasa sosial yang tinggi, sehingga masyarakatnya rukun dan tentram serta mudah beradaptasi satu sama lain.

e. Ramah Lingkungan - Produk mudah dimusnahkan dan mengandung kimia yang sangat sedikit dan tidak merusak lingkungan.

f. Ekonomis - Produk mempunyai kualitas terbaik dengan tingkat harga yang terjangkau.

3. Estetika Desain

Estetika dalam konsep desain ini mempertimbangkan beberapa aspek, meliputi :

a. Aspek Bentuk (Form and Shape)

Dalam aspek bentuk dalam pengembangan desain produk bambu nagari Kumanis ini, meliputi :

1) Wadah bambu penyimpan air Nira, dimana nagari Kumanis Sijunjung memiliki produksi gulasemut yang terbuat dari air Nira sebagai bahan bakunya.

2) Potensi Gula Semut yang dimiliki oleh nagari Kumanis sebagai potensi daerah Sijunjung.

3) Motif Sulam sebagai sebuah kerajinan tangan bagi masyarakat nagari Kumanis Sijunjung, Sumatera Barat.

b. Aspek Ornamen

Oranamen yang dimakna oleh masyarakat nagari Kumanis adalah alam (natural), sehingga pada ornamennya terdapat bentuk-bentuk motif seperti : bunga, daun dan lain-lain.

c. Aspek Material

Material digunakan jenis bambu yaitu bambu gombong/batuang sebagai material utama karena bambu menjadi tanaman yang tumbuh disekitar kebun-kebun di nagari Kumanis.

d. Aspek Citra dan Identitas

Citra dan identitas difokuskan pada nagari Kumanis, Sijunjung. Natural - alamiah, mendasar. Di dalam perancangan produk kali ini, perancangan mengambil citra atau kesan natural/alami pada produknya dengan menonjolkan karakter dan warna asli dari bambu untuk tetap diperlihatkan dan menjadi dominan pada keseluruhan desain.

e. Aspek Fungsi 
Fungsi pada produk bambu adalah bervariasi, karena pada desain terdapat berbeda-beda fungsinya mulai dari perlengkapan interior, perlengkapan alat tulis (Stationery) dan perlengkapan rumah tangga (dapur).

f. Aspek Tujuan

Merancang dan mengembangkan sebuah desain produk bambu masyarakat nagari Kumanis dengan memanfaatkan bambu - bambu menghasilkan suatu produk bambu yang memiliki nilai jual dan nilai budaya.

g. Aspek Warna

Warna pada desain produk bambu akan menyesuaikan dengan warna-warna tradisional yang dekat dengan tradisi nagari Kumanis Sijunjung dan juga akan menggunakan warna alami yang sesuai dengan warna bambu.

h. Aspek Sasaran Pengguna

Pada aspek pengguna difokuskan unisex (semua kalangan dan umur) maksudnya produk ini dapat dimiliki oleh siapa saja.

\section{J. Tahapan Desain}

Tahapan desain mencakup desain yang sudah dipilih untuk dijadikan prototype.(Lihat Gambar 4).
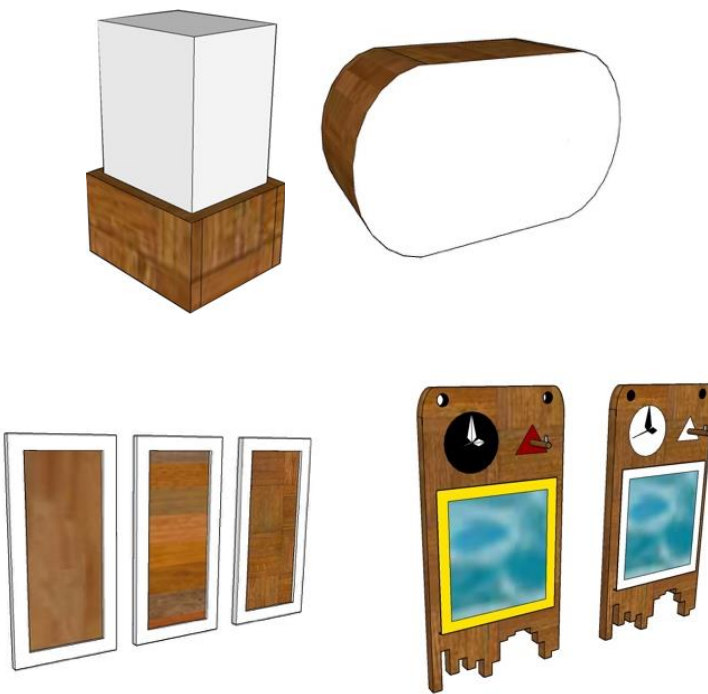

Gambar 4. Desain Terpilih (Dokumentasi : Kendall Malik, 2019)

\section{K. Prototype}

Prototype merupakan hasil dari desain terpilih yang dijadikan ukuran sebenarnya. (Lihat Gambar 5).

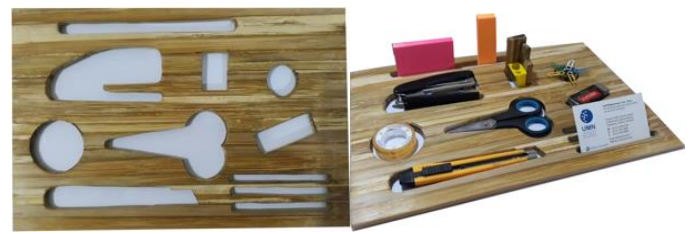

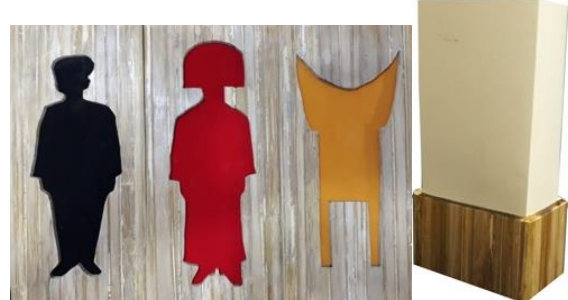

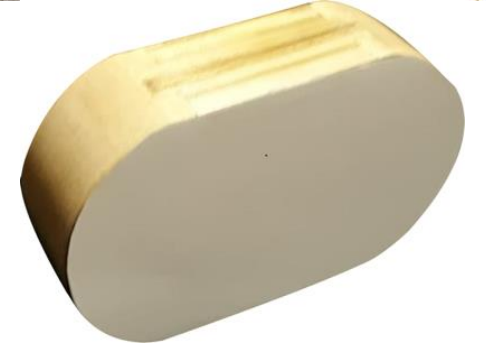

Gambar 5. Prototype

(Dokumentasi : Kendall Malik, 2019)

\section{Kesimpulan}

Berdasarkan hasil penelitian dapat disimpulkan untuk sementara, bahwa Penelitian perancangan produk bambu ini memfokuskan strategi yakni Strategi Desain yang mencakup dalam pengembangan desain. KemudianProduk yang telah dirancang mengarahkan kedalam kontek desain yang modern, bahan bambu, tidak berbahaya secara bahan dimana finishing menggunakan bahan dasar air dan natural. Kemudian mempertimbangkan nilai estetik dari produk yang dihasilkan sebagai ciri khasnya. Hasil dilakukannya pengembangan desain produk bambu Nagari Kumanis Sijunjung ini akan dapat menambah apresiasi dari perajin bambu Nagari Kumanis Sijunjung, sehingga kebutuhan akan produk bambu Nagari Kumanis akan semakin meningkat karena telah dapat dimanfaatkan dengan berbagai kegunaan. Dan itu merupakan salah satu cara yang tepat dalam pengembangan kerajinan produk bambu Daerah Sijunjung, sekaligus akan berdampak positif dalam pengembangan industri kerajinan produk bambu Nagari Kumanis Sijunjung.

Hasil dari penelitian tentunya masih jauh dari kesempurnaan namun ada bebeapa saran yang perlu untuk dicatat bahwa ada proses produksi yang penulis observasi langsung ke lapangan bahwa tempat para pengrajin bekerja sebaiknya membuat sub bagian yang terdiri dari bagian potong, bagian merakit dan bagian finishing. Karena dilihat kondidi saat sekarang ini para pengrajin kurang efisien dalam bekerja dimana mereka hanya mampu membuat sebuah produk dengan jumlah satu buah produk per hari. Kemudian tempat para pengrajin bekerja diharapkan menggunakan meja kerja untuk mengerjakan karya, karena apabila mengerjakan diatas lantai akan mengalami kelelahan dan akhir proses produksi akan terganngu dan lambat. Bagi pengrajin supaya lebih memperhatikan hasil bagus dan finishin yang maksimal, karena hasil finishin yang maksinal akan mengangkat nilai produk dimata konsumen. 


\section{Daftar Pustaka}

Badan Statistik, 2019, Kabupaten Sijunjung Dalam Angka, Penerbit Badan Pusat Statistik Kabupaten Sijunjung.

Frick, Heinz, 2004, Ilmu Konstruksi Bangunan Bambu, Konisius, Yogyakarta.

Heskett, John, 1986, Desain Industri, Rajawali, Jakarta.

Lawson, Bryan, 1980, How Designers Think, The Architectural Press, London.

Oakley, Mark, 1990, Design and Design Management, Aston University Press, United Kingdom (UK).

Panero, Julius and Zelnik, Martin, 1979, Human Dimension and Interior Space, The Architectural Press, London.

Ranjan, M.P, Iyer Nilam and P.Ghanshyam, 1986, Bamboo and Cane Crafts of Northeast India, National Institute of Design, India.

Sachari, Agus, 1986, Desain Desain Gaya dan Realitas, Rajawali Pers, Jakarta.

Ulrich.T.Karl and Eppinger.D.Steven, 1995, Product Design and Development, McGraw-Hill.Inc, Singapore.

Wolchonok, Louis, 1953, Design For Artists and Craftsmen, Dover Publications, ink, New York. 